\title{
NOISE-INDUCED GASTRIC LESIONS: a light and electron microscopy study of the rat gastric wall exposed to low frequency noise
}

\author{
Jorge FONSECA ${ }^{1}$, José MARTINS-dos-SANTOS ${ }^{1}$, Pedro OLIVEIRA ${ }^{1}$, Nuno LARANJEIRA ${ }^{1}$, \\ Artur AGUAS $^{2}$ and Nuno CASTELO-BRANCO ${ }^{3}$
}

\begin{abstract}
Context - Only a few studies evaluated the digestive alterations caused by low frequency noise (LFN) and most focused only on mucosal alterations. Objectives - To investigate the morphological injury of LFN-exposed gastric wall, beyond the epithelial layer. Methods - Wistar rats were exposed to low frequency noise (LFN), during increasing periods, 1 to 13 weeks. A control group was kept in silence. Gastric specimens were studied using: (i) light microscopy with hematoxylin-eosin and immunostaining for collagens; (ii) transmission electron microscopy; (iii) morphometry allowing statistical analysis. Results - Submucosa of all LFN-exposed animals exhibit increased thickness with fibrous proliferation. Transmission electron microscopy showed massive collagen deposition. Immunostaining identified collagen IV as responsible for the increased thickness. Morphometry allowed the demonstration of a significant difference of thickness between control and exposed groups. Vascular alterations included: i) intima proliferation and thickening, rupture of the internal elastic lamina, thrombotic changes; ii) thickening of the media; iii) after 9 weeks of LFN-exposure, we found new formed vessel presenting tortuous and twisted. There is a significant difference of arterial wall thickness between control and exposed groups. Conclusions - Deeper layers of gastric wall undergo alterations, including fibrosis of the submucosa caused by collagen IV deposition, an early marker of neoangiogenesis. Vascular alterations included thickening and thrombotic phenomena, but also images of newly formed vessels. This study suggests that, at least in the stomach, LFN-induced fibrosis could be linked with neoangiogenesis.
\end{abstract}

HEADINGS - Gastric mucosa, physiopathology. Noise effects. Microscopy, electron. Rats.

\section{INTRODUCTION}

In our modern urban societies, noise is a well recognised environmental hazard. For legal purposes, the sound description uses a unit called A-decibel, $\mathrm{dB}(\mathrm{A})$. As the human ear has a reduced sensitivity to sound in the frequencies under $500 \mathrm{~Hz}$, a sound analyser is used, with a special filter that "mimics" the human ear evaluation of sound (A-weighting). Although useful to prevent auditory diseases, $\mathrm{dB}(\mathrm{A})$ underestimates low frequency noise ( $\mathrm{LFN})$ and $\mathrm{dB}(\mathrm{A})$ measurements are inappropriate to understand noise systemic effects. In order to evaluate these noiseinduced systemic effects the "linear-weighting" must be used. Using "linear-weighting", expressed in linear decibel, $\mathrm{dB}(\mathrm{L})$, every sound frequency in the spectrum of $10-20000 \mathrm{~Hz}$ has the same sound attenuation, a physical process similar to the one that occurs when sound reaches organs and tissues. As $\mathrm{dB}(\mathrm{A})$ measurements are used for legal evaluations, environmental LFN is usually higher than measured and frequently overlooked. The scientific community has long recognized the under evaluation of $\mathrm{LFN}^{(21)}$. World Health Organization repeatedly addressed the public authorities and recommended the use of more accurate noise measurements ${ }^{(3)}$.

Most of the published medical research on noise-induced diseases is related to hearing disorders. Nevertheless, nonauditory effects of noise have been reported for decades, including gastrointestinal (GI) clinical complaints and gastric lesions. Gastric lesions were found after chronic ${ }^{(1)}$ and acute ${ }^{(5)}$ noise aggression, both in humans ${ }^{(29)}$ and animals $^{(1,29)}$. A study performed among boiler-plant workers reported GI complaints, including heartburn, stomach cramps, nausea and diarrhea ${ }^{(13)}$. After the implementation of a hearing protection program, these GI complaints increased, suggesting that the hearing protection, decreasing the audible exposure to noise, also decreased the avoidance of noise. This would increase the exposition to noise sources, which could be harmful through non-auditory pathways.

In the last three decades, most of these non-auditory effects of noise were related to the systemic effects of LFN. These included neurologic ${ }^{(31,34,41,42,48,49)}$, cardiac ${ }^{(7,33)}$, $\operatorname{vascular}^{(17,35)}$ and respiratory disorders ${ }^{(10,16,44,45,46)}$. Lesions of the parotid gland ${ }^{(47)}$ and periodontium of LFN-exposed rats were recently reported ${ }^{(38)}$. Regardless of the organs and tissues studied, the LFN-induced

'Instituto Superior de Ciências da Saúde Egas Moniz (CiiEM), Almada, Portugal; ${ }^{2}$ Instituto de Ciências Biomédicas Abel Salazar - Universidade do Porto (UMIB), Porto, Portugal; ${ }^{3}$ Center for Human Performance, Alverca, Portugal.

Correspondence: Dr. Jorge Fonseca. E-mail: jorgedafonseca@hotmail.com 
morphologic alterations seem to occur with significant fibrosis $^{(9,17,35,47)}$ and with major vascular lesions $s^{(17,35,47)}$.

LFN-induced disorders include clinically identified digestive symptoms ${ }^{(6,8)}$. Using LFN-exposed Wistar rats, we disclosed massive cell death leading to diffuse gastric erosions ${ }^{(14,19)}$. Using the same experimental model, we proved that the duodenal mucosa also developed superficial erosions ${ }^{(15)}$. Nevertheless, these upper GI lesions were restricted to the superficial mucosal layer. It was never reported any clinical or experimental study addressing the thickness of the gut wall, where important morphologic alterations could be expected.

The goal of the present study was to investigate the morphological injury of the gastric wall, beyond the epithelial layer, using light microscopy (LM), and transmission electron microscopy (TEM).

\section{METHODS}

\section{Animals}

We used adult Wistar rats weights ranging from $210 \mathrm{~g}$ to $292 \mathrm{~g}$, exposed to continuous LFN, during increasing periods:

Group 1 - 1 week (168 hours) - 10 rats

Group $2-3$ weeks (504 hours) - 10 rats

Group $3-5$ weeks (840 hours) - 10 rats

Group 4 - 9 weeks (1512 hours) - 10 rats

Group 5 - 13 weeks (2184 hours) - 10 rats

Each group had 5 males and 5 females. A control group (group C), of 15 rats ( 7 males and 8 females - weights from $209 \mathrm{~g}$ to $292 \mathrm{~g}$ ), had the same experimental conditions, but was kept in silence. They were housed in groups of 2 or 3 rats per cage, in which they could move around. They had light cycles of 12 hours day/12 hours night. All animals were fed with standard rat food, had unrestrained access to water, and were treated according with the EU directive on Animal Protection for Experimental and Scientific Purposes (86/609/EEC).

\section{Low frequency noise exposure - experimental protocol}

The rat cages were placed in front of a noise generator, consisting of a sub-woofer Magnat xtc 1200, in an isolated compartment measuring $217 \times 211 \times 195 \mathrm{~cm}$. A computer Compaq (Pentium $133 \mathrm{MHz}$ ) reproduced a "white noise" previously recorded. The sound signal was amplified with a QSC amplifier and frequencyfiltered, creating an acoustic environment rich in low frequency components. The noise exposure protocol was previously described ${ }^{(14)}$. Noise level and the spectral analysis, similar in the entire compartment, were analysed by a digital real time analyser, near the position of the LFN-exposed rats. Levels were above 90 $\mathrm{dB}$ in the frequencies ranging from 50 to $500 \mathrm{~Hz}$.

\section{Light microscopy}

Rats were sacrificed with a lethal intraperitoneal injection of pentobarbital. After removing a small fragment for electron microscopy, the stomach was removed using a procedure similar to the one described by Nakamura et al. ${ }^{(43)}$. Sections were stained with haematoxylin-eosin. Immunostaining for collagens I, IV and $\mathrm{V}$ was performed using the peroxidase technique.

\section{Transmission electron microscopy}

For TEM, the specimens were washed in phosphate buffer saline, fixed at room temperature in an aldehyde mixture made up of $4 \%$ formaldehyde, $1.25 \%$ glutaraldehyde and $10 \mathrm{nmol} / \mathrm{L} \mathrm{Ca}$ $\mathrm{Cl}_{2}$ in $0.05 \mathrm{~mol} / \mathrm{L}$ cacodylate buffer. The samples were dehydrated in ethanol and cut with a LKB microtome. The preparations were stained with uranyl acetate - lead citrate and examined in a JEOL 100C transmission electron microscope.

\section{Morphometry}

Morphometry was performed using the OPTIMAS software that allows an easy measurement of lengths and areas. In each rat, three artery images, stained with haematoxylin-eosin, were evaluated. In each artery we defined the lumen area, the wall area and the wall/lumen ratio (W/L ratio). Globally, we studied 45 arteries of control group rats and 30 arteries in each one of the $5 \mathrm{LFN}$-exposed groups. With the same software, thickness of gastric submucosa was measured in the proximal rat gastric wall (forestomach), where wall thickness is rather regular. Statistic evaluation was performed using the SPSS 13.0 program. For the W/L ratio we used the Scheffé "Post-hoc" test. For submucosal thickness evaluation we used the Welch and Brown-Forsythe tests and the Tamhane and Dunett tests.

\section{RESULTS}

We disclosed several morphologic changes on the gastric wall of LFN-exposed rats.

\section{Gastric submucosa}

Observed with LM, submucosa of all LFN-exposed animals exhibit increased thickness, more striking in the rats exposed to noise for longer periods. This increased thickness was caused by fibrous tissue proliferation that frequently invaded the muscular layer. The TEM images revealed the collagen proliferation responsible for enlargement of the submucosa (Figure 1). Staining for collagens revealed that, in control

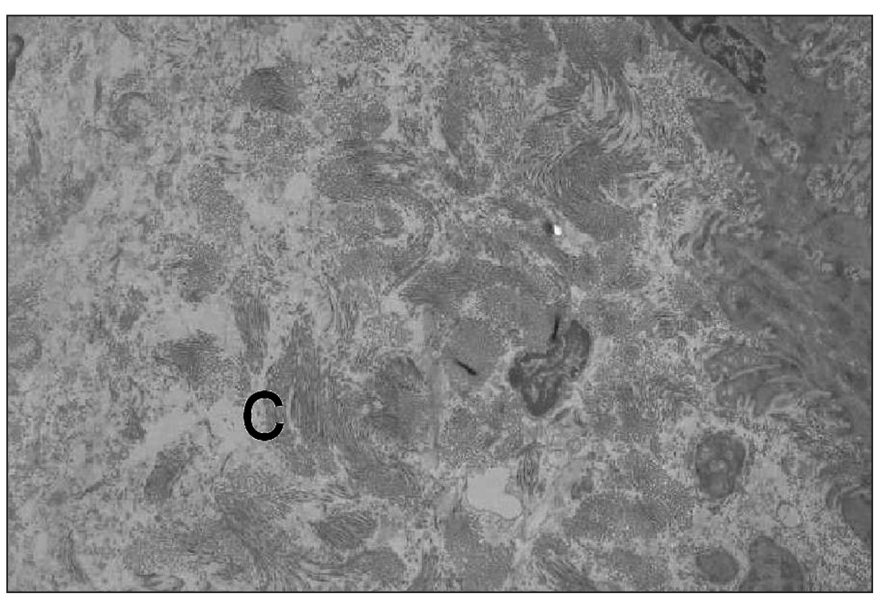

FIGURE 1. TEM images disclosing the collagen $(\mathrm{C})$ proliferation responsible for the submucosal increased thickness (x 2000) 
rats, collagen I (Figure 2a) and collagen V (Figure 3a) were very abundant and collagen IV was hardly found and just in perivascular topography (Figure 4a). The submucosa of LFN-exposed rats revealed an almost complete disappearance of collagen I (Figure 2b) and collagen V (Figure $3 b$ ). In contrast, collagen IV was greatly increased (Figure 4b) and appeared to be responsible for the increase of gastric wall thickness. Morphometry confirmed the increasing width of the submucosa (Table 1 ), starting in the earlier exposure periods. The differences between the submucosal thickness of control group and each one of the noise-exposed groups were statistically significant $(P<0.05)$. With progressive exposure the submucosa increased its thickness.

\section{Gastric arteries}

Gastric vessels and most remarkably submucosal arteries reveal significant alterations after a minimum of 3 weeks of LFN-exposure (groups 2 to 5). These alterations included: i) focal proliferation and thickening of the intima, with rupture of the internal elastic lamina, sometimes associated with thrombotic changes (Figure $5)$, ii) regular thickening of the media layer presenting eosinofilia and vacuolization (Figure 5) iii) in groups 4 and 5 ( 9 or 13 weeks of LFN-exposure), blood vessels on greater number, arteries and also veins were tortuous, convoluted and twisted (Figure 6), sometimes overlapping. These vascular changes were also present in other layers, namely in the adventitia. Morphometric evaluation confirmed the increasing $\mathrm{W} / \mathrm{L}$ ratio, an indirect assessment of increasing arterial wall width exhibiting a progressive $\mathrm{W} / \mathrm{L}$ ratio (Table 2). Group 1 had a W/L ratio similar to control group. Groups 3, 4 and 5 displayed a W/L ratio greater then control group and the Scheffé "Post-hoc" test demonstrated a statistically significant difference $(P<0.005)$.

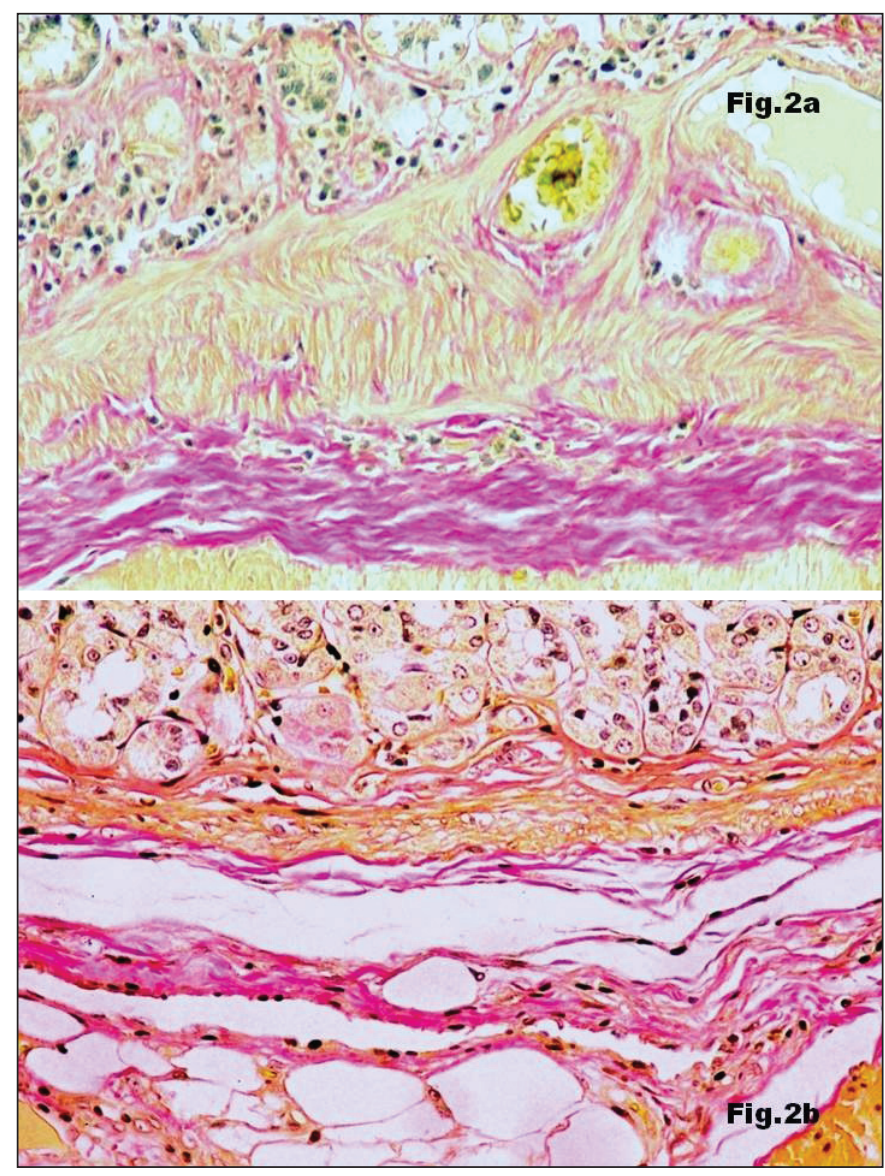

FIGURE 2. Immunostaining for collagen I (x 200): very abundant in control rat (Figure $2 \mathrm{a})$ and very reduced in the gastric wall of a rat exposed to LFN during 13 weeks (Figure $2 \mathrm{~b}$ )

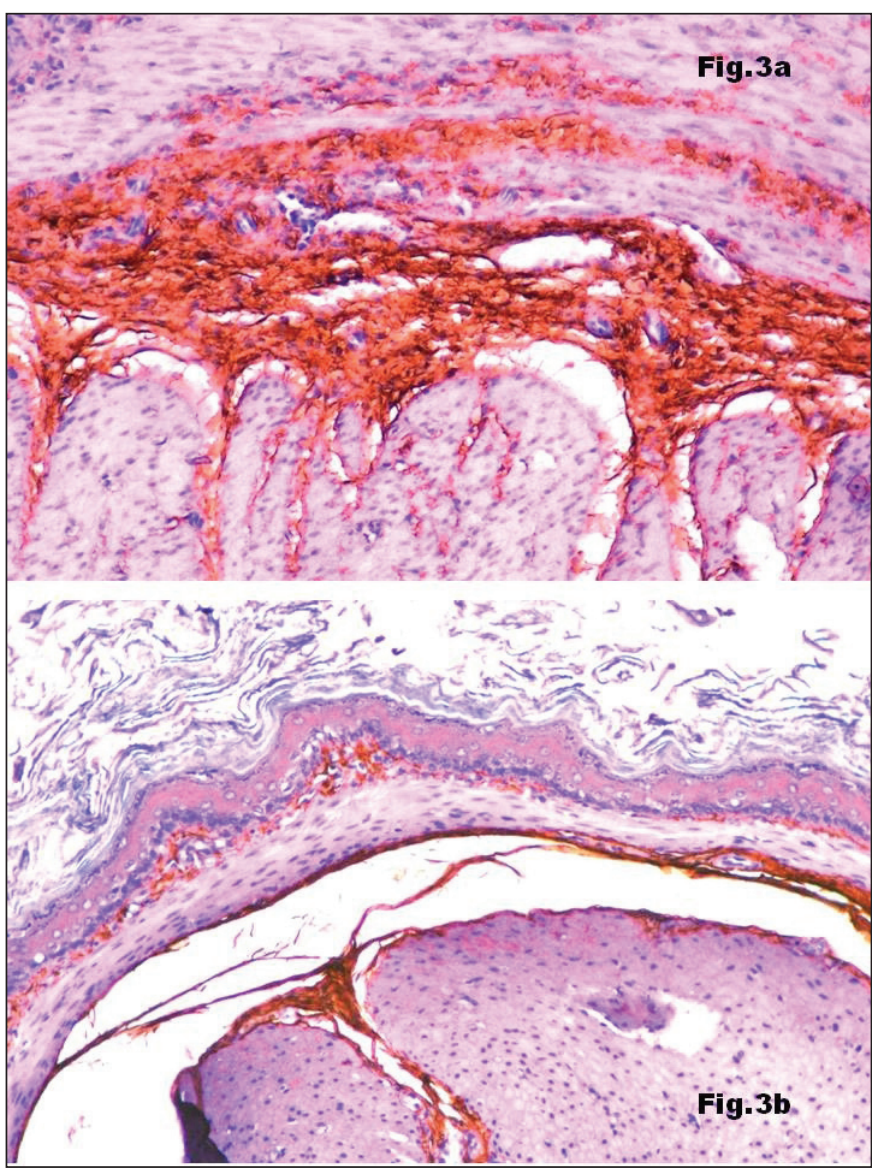

FIGURE 3. Immunostaining for collagen V (x 200): abundant in control rat (Figure $3 \mathrm{a}$ ) and almost disappeared in the gastric wall of a rat exposed to LFN during 13 weeks (Figure $3 \mathrm{~b}$ ) 


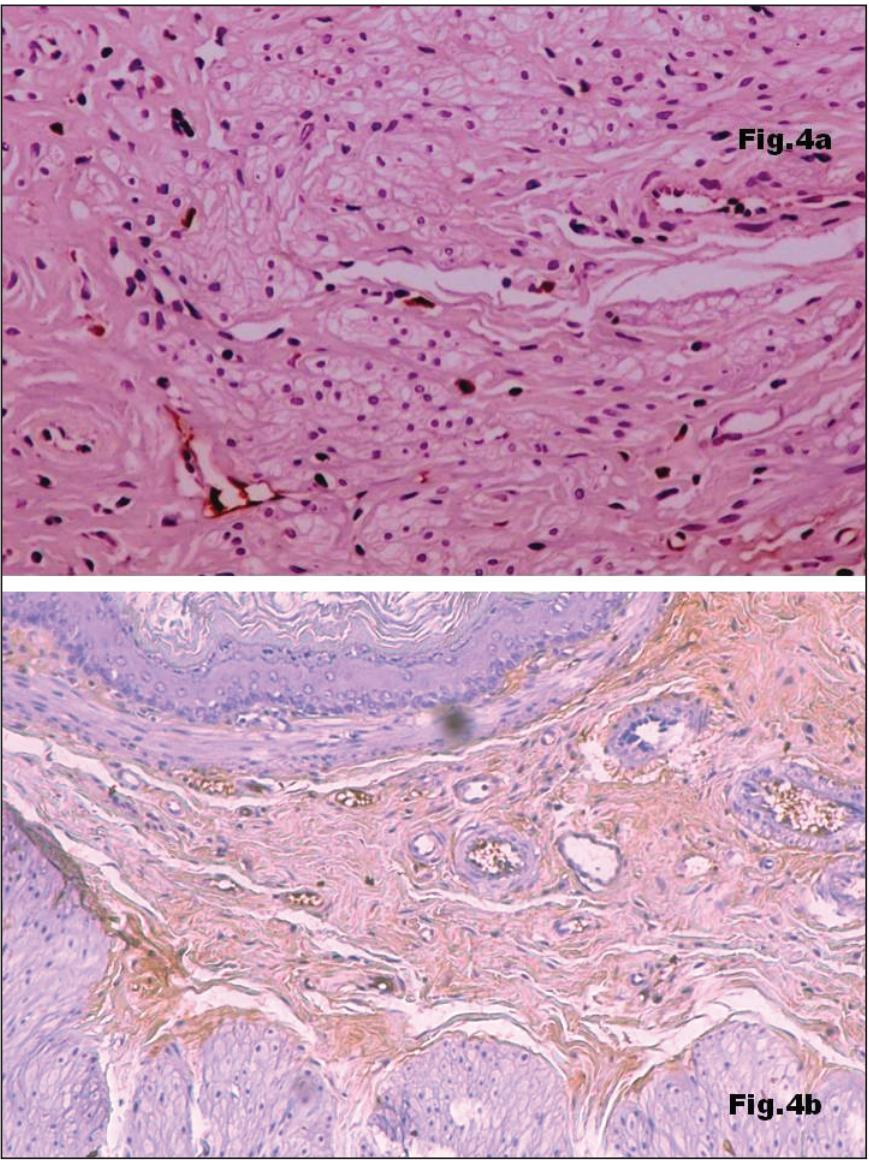

FIGURE 4. Immunostaining for collagen IV (x 200): sparse in control rat (x 200), located only in perivascular topography (Figure 4a) and abundant in gastric wall of a rat exposed to LFN during 5 weeks (x 100) causing the enlargement of the submucosa (Figure $4 \mathrm{~b}$ )

TABLE 1. Variation of the submucosal thickness according with the LFN-exposure period

\begin{tabular}{lccc}
\hline & $\begin{array}{c}\text { Number of } \\
\text { rats }\end{array}$ & $\begin{array}{c}\text { Exposure } \\
\text { period }\end{array}$ & $\begin{array}{c}\text { Submucosal } \\
\text { thickness (micra) }\end{array}$ \\
\hline Group C & 15 & $\varnothing$ & 86 \\
Group 1 & 10 & 1 week & 145 \\
Group 2 & 10 & 3 weeks & 152 \\
Group 3 & 10 & 5 weeks & 163 \\
Group 4 & 10 & 9 weeks & 177 \\
Group 5 & 10 & 13 weeks & 217 \\
\hline
\end{tabular}

TABLE 2. Variation of the wall/lumen ratio (W/L ratio) according with the LFN-exposure period

\begin{tabular}{lccc}
\hline & $\begin{array}{c}\text { Number of rats / } \\
\text { Number of arteries }\end{array}$ & $\begin{array}{c}\text { Exposure } \\
\text { period }\end{array}$ & W/L ratio \\
\hline Group C & $15 / 45$ & $\varnothing$ & $3,75($ SD: 2,32$)$ \\
Group 1 & $10 / 30$ & 1 week & 3,95 (SD:1,96) \\
Group 2 & $10 / 30$ & 3 weeks & $6,00($ SD:3,77) \\
Group 3 & $10 / 30$ & 5 weeks & $8,41($ SD:3,32) \\
Group 4 & $10 / 30$ & 9 weeks & $6,81($ SD:3,37) \\
Group 5 & $10 / 30$ & 13 weeks & $8,96($ SD:4,29) \\
\hline
\end{tabular}

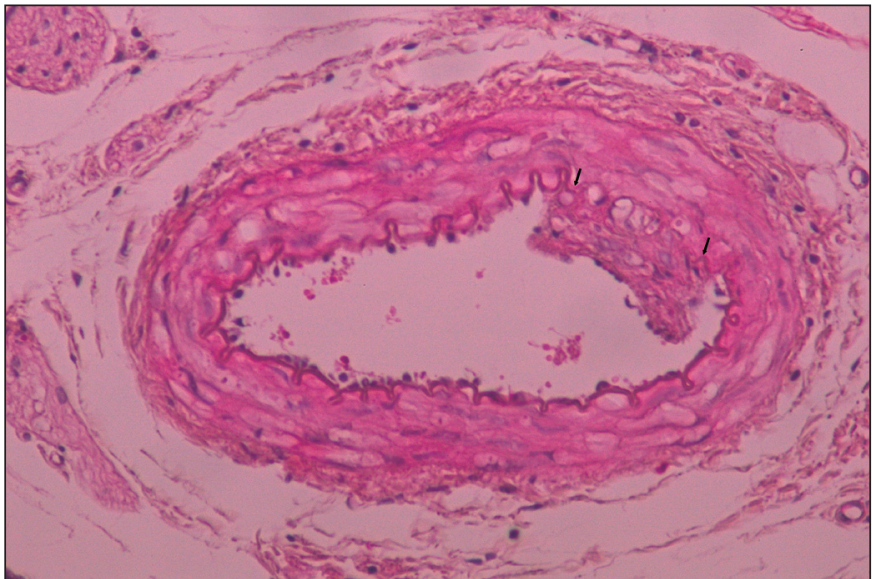

FIGURE 5. Artery of a rat exposed to LFN during 9 weeks (x 200): thickening of the intima and the media, eosinofilia and vacuolization of the media and rupture of the internal elastic lamina (arrows)

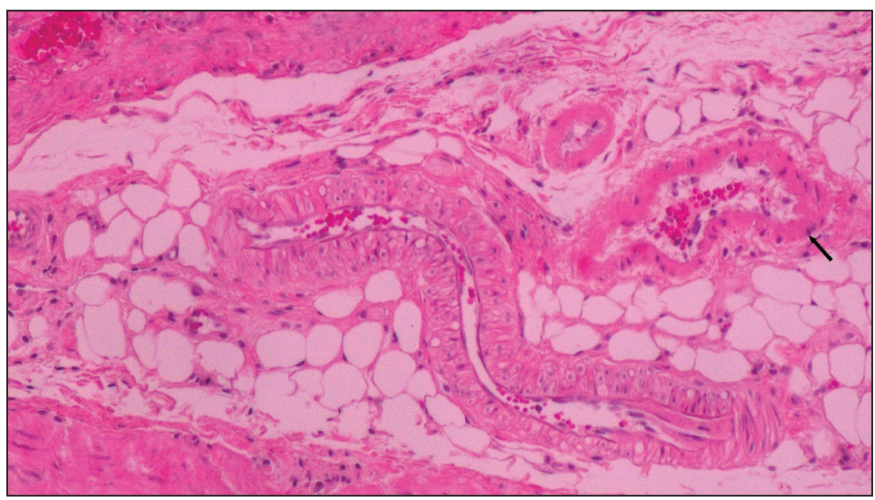

FIGURE 6. Blood vessels in greater number, arteries and also veins (arrow) tortuous, convoluted and twisted of a rat exposed to LFN during 9 weeks (x 100)

\section{DISCUSSION}

Reports had long linked non-auditory effects of noise with digestive complaints ${ }^{(13)}$ and GI lesions ${ }^{(1,29)}$. Also, the spectra of the clinical disorders caused by LFN includes gastric and gut symptoms ${ }^{(8,11)}$. Using the Wistar rat model, we had previously proved that the proximal gut suffered with LFN-exposure developing diffuse gastric ${ }^{(14,19)}$ and duodenal ${ }^{(15)}$ erosions caused by considerable epithelial cell lesion and death ${ }^{(14,19)}$. These epithelial cell lesions were similar to lesions previously found in other LFN-exposure tissues, namely the rat pleura ${ }^{(44,46)}$ and the bronchi ${ }^{(10,16,45)}$. These lesions were also similar to ulcerative lesions caused by whole-body vibration (WBV), a vibratory phenomenon comparable to noise. Most of the clinical manifestations of the "WBV disease" are related with bone and joint trauma ${ }^{(4,5)}$ causing debilitating back pain ${ }^{(27,28,30)}$ but digestive complaints are also frequent ${ }^{(39,53)}$. Lesions were found in a large group of WBV-exposed workers ${ }^{(55)}$, using endoscopy and biopsies. Nakamura et al. ${ }^{(43)}$, with an experimental 
model, produced WBV-induced gastric ulcers and proved that those ulcers were caused by direct mechanical effect of gastric vibration. Nevertheless, previous human and animal studies on LFN or WBV focused only the gastric mucosa and did not provide any understanding on the effects of vibration in deeper layers of the stomach.

Looking deeper into the gastric wall, the present study disclosed two main types of alterations of submucosa and other layers: vascular alterations and fibrosis. We found proliferation and thickening of the intima and the media, with rupture of the internal elastic lamina and thrombotic changes. These lesions were similar to those disclosed in other vessels, arteries, veins and lymphatics exposed to this kind of noise ${ }^{(17,35,47)}$. Arterial lesions in the gastric submucosa were also similar to those reported in the "hand-arm vibration syndrome" that is a well known occupational disease related with the use of vibrating tools ${ }^{(37)}$. Although joint ${ }^{(40,56)}$ and neural ${ }^{(22,32,51,52)}$ lesions are important, the syndrome seems to have a vascular pathogenesis. Clinically, it is characterised by recurrent vasospasm similar to Reynaud phenomenon ${ }^{(2,12,18,36,54)}$. Biopsies of these patients revealed thickening, fibrosis and destruction of elastic fibres ${ }^{(57)}$ analogous to the lesions found in the vessels of LFN-exposed rats in the present and previous studies ${ }^{(17,35,47)}$. The resemblance of vascular lesions occurring in LFN-exposed and directly transmitted vibration is expectable since the physical phenomenon underlying directly transmitted vibration is the same of noise and sound. Only the auditory system allows the perception of air borne vibration as sound or noise. Reaching other organs, air borne vibration is similar to directly transmitted vibration. These mechanical forces could be responsible for the destruction of elastic fibres seen in the arteries of "hand-arm vibration syndrome" patients and could cause some of the lesions observed in LFN-exposed arteries, as the rupture of the internal elastic lamina.

The other important alteration disclosed was the massive proliferation of fibrous tissue. From previous reports in other organs, we already knew that LFN-exposure was related with major fibrosis ${ }^{(9,17,20,33,35,47,50)}$. In our model, we disclose the presence of fibrous tissue enlarging the gastric submucosa of all exposed animals. Morphometric analysis proved that submucosal thickness of noise-exposed groups is significantly larger than submucosal thickness of control group.

The same mechanical forces that cause fragmentation of the elastic fibres of the arterial wall may be the cause of collagen production. Ingber ${ }^{23,24,25,26)}$ has proved that mechanical forces applied to individual cells could change cell reactions to biochemical stimuli or even induce entirely different cellular responses. Mechanical forces resulting from tissue vibration may be the initial stimulus for collagen production. Although we could not clearly identify the triggering sign of the fibrotic process, the nature of the collagen production was enlightened. The use of specific collagen immunostaining identified collagen IV as the main contributor to this increased fibrous tissue. It is known that collagen IV appears early after an aggression, associated with neoangiogenesis, and later in the repairing process new formed vessels become visible and collagen I replaces collagen $\mathrm{IV}^{(58)}$. In our model, the relationship between collagen IV and angiogenesis points towards a pathophysiologic linkage between these vascular lesions and the fibrosis. In the first weeks of LFN-exposure, vessels, most strikingly arteries, start showing thickening and thrombotic lesions. Simultaneously fibrotic changes start early: the thickness of the submucosa of 1 week exposed rats is significantly larger than the submucosa of control rats. Unlike other experimental models in which the aggression is time limited ${ }^{(58)}$, in our model the LFNexposure is continuous. Consequently, the fibrotic process is constantly induced and thickness increases with exposure. In the rats exposed for longer periods, group 4 ( 9 weeks) and group 5 (13 weeks) we observed simultaneously two features: as the persistent LFN-exposure is constantly stimulating the production of new collagen we found recently formed collagen IV, representative of the early stages of angiogenesis, but also an increased number of new vessels, frequently tortuous, convoluted and twisted, the end result of the neoangiogenesis pathway developing during 9 or 13 weeks. In the gastric wall exposed to LFN, fibrosis is due to collagen IV production and related with the neoangiogenesis process.

\section{CONCLUSIONS}

In the present study we proved that LFN-induced gastric lesions were not limited to the mucosa. Deeper layers, mainly the submucosa, also suffer important morphologic alterations. These included vascular lesions, namely thickening of the arterial walls with thrombotic phenomena. Fibrotic changes of the submucosa were caused by increased collagen IV production as part of a neoagiogenesis pathway resulting in new vessels formation after longer LFN-exposure periods. Although the presence of vascular lesions and fibrosis were long known features of LFN-exposed tissues, this study established a link between these two phenomena. At least in the gastric wall, the present data points to the collagen IV production occurring during a neoangiogenesis pathway as an important feature of the LFN-induced fibrosis. Further studies addressing hollow organs are needed, in order to evaluate the importance of neoangiogenesis in structures exposed to this kind of noise. 
Fonseca J, Martins-dos-Santos J, Oliveira P, Laranjeira N, Aguas A, Castelo-Branco N. Lesões gástricas induzidas pelo ruído: um estudo por microscopia ótica e eletrônica da parede gástrica do rato exposta a ruído de baixa frequência. Arq Gastroenterol. 2012;49(1):82-8.

RESUMO - Contexto - Só um reduzido número de estudos avaliou as alterações digestivas causadas pelo ruído de baixa frequência (RBF) e, na sua maioria, focados nas alterações da mucosa. Objetivo - Avaliar as lesões morfológicas induzidas na parede gástrica pelo RBF, para além da camada mucosa. Métodos - Ratos Wistar foram expostos a RBF, por períodos crescentes, desde 1 a 13 semanas. Um grupo controle foi mantido em silêncio. Fragmentos da parede gástrica foram estudados com recurso a: (i) microscopia ótica usando hematoxilina-eosina e imunomarcação para colágenos; (ii) microscopia eletrônica de transmissão; (iii) morfometria, permitindo a colheita de dados para análise estatística. Resultados - Observaram-se espessamento e proliferação de tecido fibroso na submucosa de todos os animais expostos aos RBF. A microscopia eletrônica de transmissão mostrou marcada deposição de colágeno. A imunomarcação identificou o colágeno IV como responsável pelo espessamento da submucosa. A morfometria permitiu demonstrar que a diferença de espessura da submucosa entre o grupo controle e os grupos de animais expostos era estatisticamente significativo. As alterações vasculares incluíram: (i) proliferação e espessamento da íntima, com rotura da lâmina elástica interna e fenômenos trombóticos; (ii) espessamento da média; (iii) após 9 semanas de exposição ao RBF, observaram-se vasos neoformados tortuosos e contorcidos. A espessura dos vasos dos animais expostos ao ruído é significativamente maior que a espessura no grupo controle. Conclusões - As camadas profundas da parede gástrica sofrem alterações que incluem fibrose causada pela deposição de colágeno IV, marcador precoce de neoangiogênese. As alterações vasculares incluem espessamento e fenômenos trombóticos e vasos neoformados. O presente estudo sugere que, pelo menos no estômago, a fibrose associada ao RBF pode estar ligada à neoangiogênese.

DESCRITORES - Mucosa gástrica, fisiopatologia. Efeitos do ruído. Microscopia eletrônica. Ratos.

\section{REFERENCES}

1. Anthony A, Harclerode JE. Noise stress in laboratory rodents: Effects of chronic noise exposure on sexual performance and reproductive function of guinea pigs. J Acoust Soc Am. 1959;31:1437-40.

2. Ariizumi M, Nakamura H, Nakamura H, Okazawa T, Okada A. Assessment of peripheral circulation under impulsive vibration or variation of temperature using the thermal diffusion method. In: 8th International Conference on Hand-Arm Vibration, 9-12 June 1998; Umea, Sweden; 1998. p.21-2.

3. Berglung B, Lindvall T, Schwela D. Guidelines for Community Noise, World Organization, WHO, Geneva, 1999.

4. Bovenzi M, Holshof CTJ. An updated review of epidemiologic studies on the relationship between exposure to whole body vibration and low back pain (19861997). Int Arch Occup Environ Health. 1999;72:351-65.

5. Bovenzi M. Health effects of mechanical vibration. G Ital Med Lav Ergon. 2005;27:58-64.

6. Branco NA, Alves-Pereira M. Vibroacoustic disease. Noise Health. 2004 6:3-20.

7. Castelo Branco NA. A unique case of vibroacoustic disease: a tribute to an extraordinary patient. Aviat Space Environ Med. 1999;70:A27-31.

8. Castelo Branco NA. The clinical stages of vibroacoustic disease. Aviat Space Environ Med. 1999;70:A32-9.

9. Castelo Branco NA, Aguas AP, Sousa Pereira A, Monteiro E, Fragata JI, Tavares $\mathrm{F}$, Grande NR. The human pericardium in vibroacoustic disease. Aviat Space Environ Med. 1999;70:A54-62.

10. Castelo Branco NA, Alves-Pereira MM, Martins dos Santos J, Monteiro E. SEM and TEM study of rat respiratory epithelia exposed to low frequency noise. In: A Mendez-Vilas, editor. Science and technology education in microscopy: an overview. Badajoz, Spain: Formatex Microscopy Book Series; 2003. p.505-33.

11. Castelo Branco NA, Alves-Pereira M. Vibroacoustic disease-current concepts. In: Proceedings of the 11th International Congress on Sound and Vibration; 2004, St. Petersburg, Russia; 2004. p.1775-82.

12. Cherniack M, Clive J, Seider A. Vibration exposure, smoking and vascular dysfunction. Occup Environ Med. 2000;57:341-7.

13. Cohen A. The influence of a company hearing conservation program on extraauditory problems in workers. J Safety Res. 1976;8:146-62.

14. Da Fonseca J, dos Santos JM, Branco NC, Alves-Pereira M, Grande N, Oliveira P, Martins AP. Noise-induced gastric lesions: a light and scanning electron microscopy study of the alterations of the rat gastric mucosa induced by low frequency noise. Cent Eur J Publ Health. 2006;14:35-8.

15. Da Fonseca J, Martins dos Santos J, Castelo Branco N, Alves-Pereira M, Grande N, Oliveira P. Noise-induced duodenal lesions. Eur J Anat. 2006;9:29-33.

16. De Sousa Pereira A, Aguas AP, Grande NR, Mirones J, Monteiro E, Castelo Branco NA. The effect of chronic exposure to low frequency noise on rat tracheal epithelia. Aviat Space Environ Med. 1999;70:A86-90.

17. dos Santos JM, Grande NR, Castelo Branco NA, Zagalo C, Oliveira P. Vascular lesions and vibroacoustic disease. Eur J Anat. 2002;6:17-21.
18. Dupuis H, Riedel S. Experience on the reversibility of the vibration-induced white finger disease. Cent Eur J Publ Health. 1995;3(suppl):19-21.

19. Fonseca J, Mirones J, Martins dos Santos J, Oliveira P, Alves-Pereira M, Castelo Branco NAA. Gastrointestinal problems in vibroacoustic disease. In: Proceedings of the 12th International Congress on Sound and Vibration; Lisbon, Portugal; 2005

20. Grande NR, Aguas AP, Sousa Pereira A, Monteiro E, Castelo Branco NAA Morphological changes in rat lung parenchyma exposed to low frequency noise. Aviat Space Environ Med. 1999;70:A70-7.

21. Hellman R, Zwicker E. Why can a decrease in $\mathrm{dB}(\mathrm{A})$ produce an increase in loudness? J Acoust Soc Am. 1987;82:1700-5.

22. Hirata M, Sakakibara H, Yamada S, Hashiguchi T, Toibana N, Koshiyama H Nerve conduction velocities in the lower extremities among patients with vibration syndrome. Cent Eur J Publ Health. 1995;3(suppl):78-80.

23. Ingber DE. Mechanical signalling and the cellular response to extracellular matrix in angiogenesis and cardiovascular physiology. Circ Res. 2002;91:877-87.

24. Ingber DE. Mechanobiology and diseases of mechanotransduction. Ann Med. 2003;35:564-77.

25. Ingber DE. Tensegrity II. How structural networks influence cellular information processing networks. J Cell Sci. 2003;116:1397-408.

26. Ingber DE. Mechanochemical basis of cell and tissue regulation. Mech Chem Biosyst. 2004;1:53-68.

27. Johanning E. Back disorders and health problems among subway train operators exposed to whole-body vibration. Scand J Work Environ Health. 1991;17:414-9.

28. Johanning E, Wilder DG, Landrigan PJ, Pope MH. Whole-body vibration exposure in subway cars and review of adverse health effects. J Occup Med. 1991;33:605-12.

29. Kim CY, Ryu JS, Hong SS. Effect of aircraft noise on gastric function. Yonsei Med J. 1968;9:149-54.

30. Kumar A, Varghese M, Mohan D, Mahajan P Gulati P, Kale S. Effect of wholebody vibration on the low back. A study of tractor-driving farmers in north India Spine 1999;24:2506-15.

31. Leventhall HG. Low frequency noise and annoyance. Noise Health. 2004;6:59-72.

32. Lundstrom R, Nilsson T, Burstrom L, Hagberg M. Vibrotactile perception densitivity and its relation to hand-arm vibration exposure. Cent Eur J Publ Health. 1995;3:62-5.

33. Marciniak W, Rodriguez E, Olszowska K, Atkov O, Botvin I, Araujo A, Pais F, Soares Ribeiro C, Bordalo A, Loureiro J, Prazeres de Sá E, Ferreira D, Castelo Branco MS, Castelo Branco NA. Echocardiographic evaluation in 485 aeronautical workers exposed to different noise environenments. Aviat Space Environ Med 1999;70:A46-53.

34. Martinho Pimenta AJ, Castelo Branco NA. Neurological aspects of vibroacoustic disease. Aviat Space Environ Med. 1999;70:A91-9.

35. Martins dos Santos J, Grande NR, Castelo Branco NAA, Zagalo C, Oliveira $\mathrm{P}$, Alves-Pereira MMS. Lymphatic lesions and vibroacoustic disease. Eur J Lymphology. 2004 12:17-20. 
36. Matoba T, Ishitake T. Cardiovascular reflexes during vibration stress. Kurume Med J. 1990;37(suppl):S61-71.

37. McGeoch KL, Lawson IJ, Burke F, Proud G, Miles J. Diagnostic criteria and staging of hand-arm vibration syndrome in the United Kingdom. Ind Health. 2005;43:527-34

38. Mendes J, Martins dos Santos J, Oliveira P, Branco NA. Low-frequency noise effects on periodontium of the Wistar rat - a light microscopy study. Eur J Anat. 2007; 11:27-30

39. Miyashita K, Morioka I, Tanabe T, Iwata H, Takeda S. Symptoms of construction workers exposed to whole-body vibration and local vibration. Int Arch Occup Environ Health. 1992;64:347-51.

40. Miyashita K, Mivamoto K, Kuruda M, Takeda S, Iwata H. Hand-arm vibration exposure and the development of vibration syndrome. Nagoya J Med Sci. 1994;57:43-8.

41. Moller H. Physiological and psychological effects of infrasound in humans. J Low Freq Noise Vib. 1984;3:1-17.

42. Moller H. Annoyance of audible infrasound. J Acoust Soc Am. 1985;78:s32.

43. Nakamura H, Katoh A, Nohara S, Nakamura H, Okada A. Experimenta studies on the pathogenesis of the gastric mucosal lesions induced by whole-body vibration. Environ Res. 1992;58:220-9.

44. Oliveira MJ, De Sousa Pereira A, Aguas AP, Grande NR, Monteiro E, Serrano I, Castelo Branco NA. Effects of low frequency noise upon the reaction of pleural milky spots to mycobacterial infection. Aviat Space Environ Med. 1999;70:A137-54.

45. Oliveira MJ, Pereira AS, Guimarães L, Freitas D, Carvalho AP, Grande NR, Águas AP. Chronic exposure of rats to cotton-mill-room noise changes the cell composition of the tracheal epithelium. J Occup Environ Med. 2002; $44: 1135-42$.

46. Oliveira MJ, Pereira AS, Ferreira PG, Grande NR, Aguas AP, Guimarães L, Freita D, Carvalho AP. Reduction of rat pleural microvilli caused by noise pollution. Exp Lung Res. 2003;29:445-54

47. Oliveira PM, Pereira da Mata AD, Martins dos Santos JA, da Silva Marques DN, Branco NC, Silveira JM, Correia da Fonseca JC. Low-frequency noise effects on the parotid gland of the Wistar rat. Oral Dis. 2007;13:468-73.
48. Persson Waye K. Effects of low frequency noise on sleep. Noise Health. 2004;6:87-91.

49. Pimenta MG, Martinho Pimenta AJ, Castelo Branco MS, Silva Simoes JM, Castelo Branco NA. ERP P300 and brain magnetic resonance in patients with vibroacoustic disease. Aviat Space Environ Med. 1999;70:A107-14.

50. Reis Ferreira JM, Couto AR, Jalles-Tavares N, Castelo Branco MS, Castelo Branco NA. Air flow limitation in patients with vibroacoustic disease. Aviat Space Environ Med. 1999;70:A63-9.

51. Sakakibara H, Hirata M, Hashiguchi T, Toibana N, Koshiyama H, Zhu SK, Yamada S. Digital nerve conduction velocity for evaluation of peripheral nerve impairments in vibration syndrome. Cent Eur J Publ Health. 1995:3:52-3.

52. Sakakibara H, Yamada S. Vibration syndrome and autonomic nervous system. Cent Eur J Publ Health. 1995;3:11-4.

53. Seidel H, Heide R. Long-term effects of whole-body vibration: a critical survey of the literature. Int Arch Occup Environ Med 1986;58:1-26.

54. Stoyneva Z, Lyapina M, Tzevetkov D, Vodenicharov E. Current pathophysiological views on vibration induced Raynaud's phenomenon. Cardiovasc Res. 2003;57:615-24

55. Sukharevskaia TM, Nepomniashchikh GI, Bobrova SV, Belov IIu, Aidagulova SV, Lapii GA. Clinical endoscopic and pathomorphologic study of the stomach in vibration disease. Med Tr Prom Ekol. 1999:(6):16-9.

56. Sutinen P, Koskimies K, Aalto H, Stark J, Pyykko I. Shoulder and elbow musculoskeletal disorder in forest workers exposed to hand-arm vibration. In Proceedings of the Eighth International Conference on Hand-Arm Vibration; 1998; Umea, Sweden, 1998. p.193-8.

57. Takeuchi T, Futatsuka M, Imanishi H, Yamada S. Pathological changes observed in the finger biopsy of patients with vibration-induced white finger. Scand J Work Environ Health. 1986;12:280-3

58. Teles-Grilo ML, Leite-Almeida H, Martins dos Santos J, Oliveira C, Boaventura P, Grande NR. Differential expression of collagens type I and type IV in lymphangiogenesis during the angiogenic process associated with bleomycininduced pulmonary fibrosis in rat. Lymphology. 2005;38:130-5.

Received 25/9/2011 Accepted 10/10/2011 